\title{
Effect of Extraction Methods on the Active Compounds and Antioxidant Properties of Ethanolic Extracts of Echinacea purpurea Flower
}

\author{
Yi-Lin Chen, Jih-Min Sung, Sheng-Dun Lin* \\ Department of Food Science and Technology, Hungkuang University, Taichung, Taiwan \\ Email: $\underline{\text { *lin54@sunrise.hk.edu.tw }}$
}

Received 6 December 2014; accepted 17 January 2015; published 20 January 2015

Copyright (C) 2015 by authors and Scientific Research Publishing Inc.

This work is licensed under the Creative Commons Attribution International License (CC BY). http://creativecommons.org/licenses/by/4.0/

c) (†) Open Access

\begin{abstract}
The extraction yields, active compounds and antioxidant properties of 50\%-aqueous-ethanolic extracts of freeze-dried Echinacea purpurea flower with multi-steps and multi-batches extraction methods were assessed. In multi-steps extraction, the extraction yields of 1st, $2 \mathrm{nd}$, and 3rd extracts were $21.52 \%, 9.33 \%$, and $2.90 \%$, and their total phenols contents were $182.08,176.33$, and $177.08 \mathrm{mg} \mathrm{CAE} / \mathrm{g}$, respectively, with cichoric acid $(62.07-66.57 \mathrm{mg} / \mathrm{g})$ being the main phenolic compound. No differences in the contents of individual and total caffeic acids derivates existed among 1st, 2nd, and 3rd extracts. The dodeca-2E, 4E, 8Z, 10(E/Z)-tetraenoic acid isobutylamide (alkamide 8/9) contents of $1 \mathrm{st}, 2 \mathrm{nd}$, and 3rd extracts were $505.38,598.61$, and $585.99 \mu \mathrm{g} / \mathrm{g}$, respectively. In multi-batches extraction, the extracted dry weight increased with increasing the sample batches, with the extraction yields and alkamide 8/9 contents of samples decreased from $19.93 \%$ to $12.98 \%$ and 534.36 to $269.76 \mu \mathrm{g} / \mathrm{g}$, respectively. The total phenol (177.25 - $186.92 \mathrm{mg}$ CAE/g), individual and total caffeic acid derivatives $(85.99-95.06 \mathrm{mg} / \mathrm{g})$ contents of extracts among different sample batches were not significantly different, with cichoric acid (63.66 - 70.31 $\mathrm{mg} / \mathrm{g}$ ) being the main phenolic compound. All the prepared extracts also exhibited potent antioxidant properties. Overall, the two-step sequential extraction is desirable for extracting bioactive compounds from freeze-dried E. purpurea flower.
\end{abstract}

\section{Keywords}

Echinacea purpurea, Extraction, Active Component, Antioxidant

\footnotetext{
${ }^{*}$ Corresponding author.
}

How to cite this paper: Chen, Y.-L., Sung, J.-M. and Lin, S.-D. (2015) Effect of Extraction Methods on the Active Compounds and Antioxidant Properties of Ethanolic Extracts of Echinacea purpurea Flower. American Journal of Plant Sciences, 6, 201212. http://dx.doi.org/10.4236/ajps.2015.61023 


\section{Introduction}

Echinacea purpurea L. is frequently used to alleviate colds, sore throats and other upper respiratory infections. Many types of Echinacea products (e.g., infusions, tinctures and capsules) are used to stimulate immune system. The immuno-stimulating properties of Echinacea products are mainly attributed to its bioactive phytochemicals including caffeic acid derivatives, alkamides, polysaccharides, and glycoproteins. Among these phytochemicals, caffeic acid derivatives, especially cichoric acid, possess many bioactive functions including anti-hyaluronidase activity, protection of collagen from free radical induced degradation, antiviral activity, inhibition of human immunodeficiency virus type 1 integrase and replication, promoting phagocyte activity in vitro and in vivo, a high free radical scavenging property and inhibition of human colon cancer cells growth [1]-[4]. Alkamides are reported to be a new class of cannabinomimetics modulating tumor necrosis factor $\alpha$ (TNF- $\alpha$ ) gene expression via the cannabinoid type $2\left(\mathrm{CB}_{2}\right)$ receptor [5] [6]. They have exhibited a strong stimulating effect on phagocyte function and on lipoxygenase-inhibiting activity [1] [5]-[8]. Thus, cichoric acid and alkamides are commonly used as marker to determine the medicinal quality of Echinacea products [9].

Various extraction techniques have been developed to obtain phytochemicals from plant materials [10]. Many extraction methods, including solvent extraction (with or without mechanical agitation), and some novel techniques such as sonication-assisted and microwave-assisted extractions, are used to extract phytochemicals from various plant materials. Nevertheless, from commercial-scale production viewpoint, the selected extraction technique must be versatile, simple, low-cost and safe for both the operating personnel and the consumers [11]. In Taiwan, the classical solvent extraction coupled with higher temperature has been commercially used to extract bioactive compounds from various plant species for years.

E. purpurea has recently been grown in Taiwan for years. The total phenols and caffeic acid derivatives contents in different E. purpurea parts were in the descending order: flowers $>$ leaves $>$ stems $>$ roots [12]. The optimal extraction conditions of $E$. purpurea flowers were $50 \%$ ethanol and $65^{\circ} \mathrm{C}$ of extracting temperatures, and its ethanolic extract exhibited good antioxidant, antimutaginic, and anticancer activities in previous study [4] [13]. However, in solid-liquid extraction technique, a single extraction is generally not sufficient to remove all the phenolic compounds comparing to multiple extractions [14]. Therefore, the objectives of this study were to investigate the effects of multi-steps extraction and multi-batches extraction methods on the extraction yields, active compounds and antioxidant properties of the $50 \%$ ethanolic extracts of freeze-dried E. purpurea flower.

\section{Material and Methods}

\subsection{Plant Materials and Chemicals}

The flowers of E. purpurea (L.) Moench variety CLS-P2 harvested from six-month-old plants were donated by Echili Biotechnology (Dali, Taichung, Taiwan). The flowers were freeze-dried with vacuum on the same day as harvested. The dried flowers were ground in a mill, and screened through a $2.0 \mathrm{~mm}$ sieve. The particle size distribution of dried flower powders was $>1.680 \mathrm{~mm}(0.01 \%), 0.840-1.680 \mathrm{~mm}(1.74 \%), 0.149-0.840 \mathrm{~mm}$ (75.31\%), $0.074-0.149 \mathrm{~mm}(13.74 \%)$, and $<0.074 \mathrm{~mm}(9.20 \%)$. The dried flower powders were sealed in a $\mathrm{PET} / \mathrm{Al} / \mathrm{PE}$ bag and then kept at $-20^{\circ} \mathrm{C}$ before use.

Methanol, acetonitrile and phosphoric acid were purchased from Mallinckrodt Baker, Inc. (New Jersey, USA). Echinacoside and dodeca-2E, 4E, 8Z, 10(E/Z)-tetraenoic acid isobutylamide (alkamide 8/9) were purchased from ChromaDex Inc. (Santa Ana, CA, USA). Caftaric acid, chlorogenic acid, cichoric acid, caffeic acid, FolinCiocalteu's phenol reagent, 1,1-diphenyl-2-picrylhydrazyl (DPPH), trichloroacetic acid, potassium ferricyanide, ferrous chloride, ferrozine, ascorbic acid, $\alpha$-tocopherol, butylated hydroxyanisole (BHA), and ethylenediaminetetraacetic acid (EDTA) were purchased from Sigma-Aldrich Chemical Co. (St. Louis, MO, USA). Anhydrous sodium carbonate was purchased from Shimakyu's Pure Chemicals (Osaka, Japan). Ferric chloride was purchased from Wako Pure Chemical Industries Co. (Osaka, Japan). Sodium phosphate was purchased from Union Chemical Work Ltd. (Hsinchu, Taiwan). Ethanol (95\%) was purchased from Taiwan Tobacco \& Liquor Co. (Tainan, Taiwan).

\subsection{Extraction of Active Compounds from E. purpurea Flowers}

\subsubsection{Multi-Steps Extraction Method}

The extract was obtained according to the methods of Tsai et al. [13] with minor modifications. The freeze-dried 
flower powders ( $15 \mathrm{~g}$ for each sample) were extracted with $150 \mathrm{ml}$ of $50 \%$ aqueous ethanol in a shaking bath at $100 \mathrm{rpm}$ for $30 \mathrm{~min}$ under $65^{\circ} \mathrm{C}$ conditions, and then centrifuged at $3460 \times \mathrm{g}$ for $10 \mathrm{~min}$, filtered through Advantec No. 1 filter paper. The residue was re-extracted twice with two extra $150 \mathrm{ml}$ portions of solvent as described above. The first, second and third extracts were designated as 1st, 2nd and 3rd, respectively. Each ethanolic extract was rotary evaporated at $40^{\circ} \mathrm{C}$ and then freeze-dried with vacuum. The resultant dry extracts were stored at $-20^{\circ} \mathrm{C}$ before use. All experiments were done in triplicate.

\subsubsection{Multi-Batches Extraction Method}

The freeze-dried flower powders ( $15 \mathrm{~g}$ for each sample) were extracted with $150 \mathrm{ml}$ of $50 \%$ aqueous ethanol in a shaking bath at $100 \mathrm{rpm}$ for $30 \mathrm{~min}$ under $65^{\circ} \mathrm{C}$ conditions, and then centrifuged at $3460 \times g$ for $10 \mathrm{~min}$, filtered through Advantec No. 1 filter paper. The ethanolic extract was rotary evaporated at $40^{\circ} \mathrm{C}$ and then freeze-dried with vacuum. The extract was designated as I. The filtrate from I was adjusted to $150 \mathrm{ml}$ with $50 \%$ aqueous ethanol to extract another batch freeze-dried flower powders (15 g). The extract was designed as II. The filtrate from II was adjusted to $150 \mathrm{ml}$ with $50 \%$ aqueous ethanol to extract another batch freeze-dried flower powders (15 g). The extract was designed as III. The filtrate from III was adjusted to $150 \mathrm{ml}$ with $50 \%$ aqueous ethanol to extract another batch freeze-dried flower powders $(15 \mathrm{~g})$. The extract was designed as IV. Each ethanolic extract was rotary evaporated at $40^{\circ} \mathrm{C}$ and then freeze-dried with vacuum. Dried extracts were stored at $-20^{\circ} \mathrm{C}$ before use. All experiments were done in triplicate.

\subsection{Determination of Total Phenols}

The content of total phenols in the extracts was determined using Folin-Ciocalteu's colorimetric method according to the method of Wu et al. [11] with minor modifications. The prepared extract (40 mg) was dissolved in $70 \%$ aqueous methanol $(5.0 \mathrm{ml}$ ) using an ultrasonic bath with $40 \mathrm{kHz}$ for $5 \mathrm{~min}$, and then the volume was adjusted to $10 \mathrm{ml}$. A sample solution of $100 \mu \mathrm{l}$ was mixed with $2.5 \mathrm{ml}$ deionised water, followed by the addition of $0.1 \mathrm{ml}(2 \mathrm{~N})$ Folin-Ciocalteu's phenol reagent. The mixture was well stirred and allowed to stand for 6 min before $0.5 \mathrm{ml}$ of a $20 \%$ sodium carbonate solution was added and then the volume was adjusted to $10 \mathrm{ml}$ with deionised water. The color developed after $30 \mathrm{~min}$ at room temperature and the absorbance was measured at 760 $\mathrm{nm}$ using a UV-visible spectrophotometer, with chlorogenic acid used as a standard. The content of total phenols was calculated on the basis of the calibration curve of chlorogenic acid [the equation of standard curve: absorbance at $\left.760 \mathrm{~nm}=0.0005 \mathrm{C}_{\text {chlorogenic acid }}(\mu \mathrm{g} / \mathrm{ml})+0.0295, \mathrm{R}^{2}=0.994\right]$. Result was expressed as milligram of chlorogenic acid equivalents (CAE) per gram of dry extract. Each analysis was carried out in triplicate.

\subsection{Determination of Caffeic Acid Derivatives}

The content of caffeic acid derivatives in the prepared extract was determined according to the methods of $\mathrm{Hu}$ and Kitts [15] and Pellati et al. [3] with minor modifications. Briefly, the extract (40 mg) was dissolved in 70\% ethanol (5.0 ml) using an ultrasonic bath with $40 \mathrm{kHz}$ for $5 \mathrm{~min}$, and the volume was adjusted to $10 \mathrm{ml}$, and then centrifuged at $1400 \times g$ for $5 \mathrm{~min}$. The solution was filtered using a PVDF syringe filter $(13 \mathrm{~mm} \times 0.45 \mu \mathrm{m})$ prior to injection onto a HPLC. The HPLC system consisted of a Hitachi L-2130 pump, a Hitachi L-2400 UV detector, and a Luna $5 \mathrm{u} \mathrm{C18(2)} \mathrm{100A} \mathrm{column} \mathrm{(} 250 \mathrm{~mm} \times 4.6 \mathrm{~mm}, 5 \mu \mathrm{m}$, Phenomenex Co., USA). The column temperature was maintained at $35^{\circ} \mathrm{C}$. The mobile phase was (A) acetonitrile/water containing $0.1 \% \mathrm{H}_{3} \mathrm{PO}_{4}(10: 90)$ and (B) acetonitrile/water containing $0.1 \% \mathrm{H}_{3} \mathrm{PO}_{4}$ (25:75). A gradient elution profile was used with $\mathrm{B}$ increasing from $0 \%$ to $100 \%$ in $30 \mathrm{~min}$ and maintained at $100 \%$ for $10 \mathrm{~min}$. Then a linear gradient of $100 \% \mathrm{~B}$ decreased to $0 \mathrm{~B}$ in $10 \mathrm{~min}$. The flow rate was $1.5 \mathrm{ml} / \mathrm{min}$, and the wavelength of the UV-visible detector was set at $330 \mathrm{~nm}$. The sample injection volume was $10 \mu \mathrm{l}$. Contents of various caffeic acid derivatives were calculated on the basis of the calibration curve of each caftaric acid, chlorogenic acid, caffeic acid, echinacoside and cichoric acid. Each analysis was carried out in triplicate.

\subsection{Determination of Alkamide 8/9}

The content of alkamide 8/9 in the extracts was determined according to the methods of Perry et al. [16] and Bergeron et al. [17] with minor modifications. Briefly, each extract (40 mg) was dissolved in 70\% ethanol (5.0 $\mathrm{ml}$ ) using an ultrasonic bath with $40 \mathrm{kHz}$ for $5 \mathrm{~min}$, and the volume was adjusted to $10 \mathrm{ml}$, and then centrifuged 
at $1400 \times g$ for $5 \mathrm{~min}$. The solution was filtered using a PVDF syringe filter $(13 \mathrm{~mm} \times 0.45 \mu \mathrm{m})$ prior to injection onto a HPLC. The HPLC system consisted of a Hitachi L-2130 pump, a Hitachi L-2400 UV detector, and a LiChrospher $^{\circledR} 100$ RP-18e column $(250 \mathrm{~mm} \times 4.6 \mathrm{~mm}, 5 \mu \mathrm{m}$, Merck Co., Germany). The column temperature was maintained at $25^{\circ} \mathrm{C}$. The mobile phase was (A) acetonitrile and (B) water. A gradient elution profile was used with B decreasing from $60 \%$ to $20 \%$ in 15 min and maintained at $20 \%$ for $5 \mathrm{~min}$. Then a linear gradient of $20 \% \mathrm{~B}$ increased to $60 \% \mathrm{~B}$ in $10 \mathrm{~min}$. The flow rate was $1.5 \mathrm{ml} / \mathrm{min}$, and the wavelength of the UV-visible detector was set at $254 \mathrm{~nm}$. The sample injection volume was $20 \mu \mathrm{l}$. Contents of alkamide $8 / 9$ were calculated on the basis of the purchased alkamide 8/9 standard. Each analysis was carried out in triplicate.

\subsection{Antioxidant Properties}

\subsubsection{Scavenging Ability on DPPH Radicals}

For DPPH radicals scavenging ability assay [18], each extract $(30-150 \mu \mathrm{g} / \mathrm{ml}, 4 \mathrm{ml})$ in methanol was mixed with $1 \mathrm{ml}$ of methanolic solution containing DPPH radicals, resulting in a final concentration of $0.5 \mathrm{mM}$ DPPH. The mixture was shaken vigorously and left to stand for $30 \mathrm{~min}$ in the dark, the absorbance of the mixture was then measured at $517 \mathrm{~nm}$ against a blank. Ascorbic acid, BHA, and $\alpha$-tocopherol were used for comparison. $\mathrm{EC}_{50}$ value ( $\mu \mathrm{g}$ extract $\left./ \mathrm{ml}\right)$ is the effective concentration at which DPPH radicals were scavenged by $50 \%$.

\subsubsection{Reducing Power}

The reducing power was determined according to the method of Oyaizu [19]. Each extract (100 - $500 \mu \mathrm{g} / \mathrm{ml}, 2.5$ $\mathrm{ml}$ ) in methanol was mixed with $2.5 \mathrm{ml}$ of $200 \mathrm{mM}$ sodium phosphate buffer (pH 6.6) and $2.5 \mathrm{ml}$ of $1 \%$ potassium ferricyanide, and the mixture was incubated at $50^{\circ} \mathrm{C}$ for $20 \mathrm{~min}$. After $2.5 \mathrm{ml}$ of $10 \%$ trichloroacetic acid $(\mathrm{w} / \mathrm{v}$ ) were added, the mixture was centrifuged at $2600 \times g$ for $10 \mathrm{~min}$. The upper layer ( $3 \mathrm{ml}$ ) was mixed with 3 $\mathrm{ml}$ of deionized water and $0.6 \mathrm{ml}$ of $0.1 \%$ ferric chloride, and the absorbance of the mixture was measured at $700 \mathrm{~nm}$ against a blank to determine the amount of ferric ferrocyanide (Prussian blue) formed. Ascorbic acid, BHA, and $\alpha$-tocopherol were used for comparison. $\mathrm{EC}_{50}$ value $(\mu \mathrm{g}$ extract $/ \mathrm{ml})$ is the effective concentration at which the absorbance was 0.5 for reducing power.

\subsubsection{Ferrous Ions Chelating Abilities}

Chelating ability was determined according to the method of Dinis et al. [20]. Each extract (1 - $5 \mathrm{mg} / \mathrm{ml}, 1 \mathrm{ml})$ in methanol was mixed with $3.7 \mathrm{ml}$ of methanol and $0.1 \mathrm{ml}$ of $2 \mathrm{mM}$ ferrous chloride. After $30 \mathrm{~s}$ of standing, 0.2 $\mathrm{ml}$ of $5 \mathrm{mM}$ ferrozine was added. After $10 \mathrm{~min}$ at room temperature, the absorbance of the mixture was determined at $562 \mathrm{~nm}$ against a blank. The EDTA, ascorbic acid, BHA, and $\alpha$-tocopherol were used for comparison. $\mathrm{EC}_{50}$ value $(\mathrm{mg}$ extract $/ \mathrm{ml})$ is the effective concentration at which ferrous ions were chelated by $50 \%$.

\subsection{Statistical Analysis}

All measurements were carried out in triplicate. All data were subjected to analysis of variance using the Statistical Analysis System software package (SAS Institute, Cary, NC, USA). When a significant difference was found among treatments, Duncan's multiple range tests were performed to determine the differences among the mean values at the level of $\alpha=0.05$.

\section{Results and Discussion}

\subsection{Effect of Multi-Steps Sequential Extraction Method on the Extraction Yields and Active Compounds}

The extraction weights and yields of E. purpurea flower extracts obtained by a sequential extraction in three steps were shown in Table 1 . The extract dry weight and extraction yield obtained from $15 \mathrm{~g}$ sample was 5.0629 g and 33.75\%, respectively. The extraction yield was slightly lower than the value of 39.8\% reported by Tsai et al. [13]. This result was not unexpected because only the petals were used in the study of Tsai et al. [13]. But in the present study both petals and receptacles were used for extraction. When the extraction steps were compared separately, the percentage of extract dry weight obtained from 1st-, 2nd- and 3rd-step extraction was 63.76\%, $27.64 \%$, and $8.60 \%$ of total extracted dry weight (summation of 1st, 2nd and 3rd extracts), respectively. How- 
Table 1. The weight, extraction yields and active compounds contents of freeze-dried extracts from freeze-dried Echinacea purpurea flower with multi-steps extraction method.

\begin{tabular}{|c|c|c|c|c|c|}
\hline \multirow{2}{*}{ Quality characteristics } & \multicolumn{4}{|c|}{ Number of Extraction } & \multirow{2}{*}{$\begin{array}{c}\text { Freezed-dried } \\
\text { flower }\end{array}$} \\
\hline & 1st & 2nd & 3rd & $1 s t+2$ nd + 3rd & \\
\hline Weight (g) & $3.2284 \pm 0.2098 \mathrm{~A}^{a}$ & $1.4002 \pm 0.0509 \mathrm{~B}$ & $0.4343 \pm 0.0197 \mathrm{C}$ & $5.0629 \pm 0.1495$ & \\
\hline Extraction yield $^{b}(\%)$ & $21.52 \pm 1.40 \mathrm{~A}$ & $9.33 \pm 0.34 \mathrm{~B}$ & $2.90 \pm 0.13 \mathrm{C}$ & $33.75 \pm 1.00$ & \\
\hline Total phenols (mg CAE/g) & $182.08 \pm 3.74 \mathrm{~A}$ & $176.33 \pm 4.93 \mathrm{~B}$ & $177.08 \pm 4.27 \mathrm{~B}$ & $180.06 \pm 3.96$ & $60.78 \pm 1.32$ \\
\hline \multicolumn{6}{|l|}{$\begin{array}{c}\text { Caffeic acid } \\
\text { derivatives (mg/g) }\end{array}$} \\
\hline Caftaric acid & $19.97 \pm 1.40 \mathrm{~A}$ & $19.89 \pm 0.63 \mathrm{~A}$ & $19.61 \pm 1.43 \mathrm{~A}$ & $19.92 \pm 1.19$ & $6.72 \pm 0.11$ \\
\hline Chlorogenic acid & $2.98 \pm 0.25 \mathrm{~A}$ & $2.58 \pm 0.21 \mathrm{AB}$ & $2.34 \pm 0.16 \mathrm{~B}$ & $2.81 \pm 0.23$ & $0.95 \pm 0.01$ \\
\hline Caffeic acid & $0.40 \pm 0.02 \mathrm{~A}$ & $0.41 \pm 0.04 \mathrm{~A}$ & $0.38 \pm 0.04 \mathrm{~A}$ & $0.40 \pm 0.03$ & $0.14 \pm 0.01$ \\
\hline Echinacoside & $1.09 \pm 0.10 \mathrm{~A}$ & $1.09 \pm 0.13 \mathrm{~A}$ & $1.09 \pm 0.21 \mathrm{~A}$ & $1.09 \pm 0.12$ & $0.37 \pm 0.02$ \\
\hline Cichoric acid & $66.57 \pm 3.53 \mathrm{~A}$ & $66.54 \pm 1.26 \mathrm{~A}$ & $62.07 \pm 2.14 \mathrm{~A}$ & $66.18 \pm 2.78$ & $22.34 \pm 0.20$ \\
\hline Total caffeic acid derivatives & $91.01 \pm 5.29 \mathrm{~A}$ & $90.51 \pm 2.14 \mathrm{~A}$ & $85.49 \pm 3.90 \mathrm{~A}$ & $90.40 \pm 4.30$ & $30.51 \pm 0.32$ \\
\hline Alkamide $8 / 9^{c}(\mu \mathrm{g} / \mathrm{g})$ & $505.38 \pm 28.52 \mathrm{~B}$ & $598.61 \pm 25.66 \mathrm{~A}$ & $585.99 \pm 36.46 \mathrm{~A}$ & $538.08 \pm 20.87$ & $181.62 \pm 15.28$ \\
\hline
\end{tabular}

${ }^{a}$ Each value is expressed as mean \pm standard deviation $(\mathrm{n}=3)$. Means with different capital letter within a row are significantly different $(P<0.05)$; ${ }^{b}$ Extraction yield $(\%)=($ dried extract weight/sample weight $) \times 100 \%$; ${ }^{c}$ Alkamide $8 / 9$ : dodeca-2E, $4 E$, $8 Z, 10(E / Z)$-tetraenoic acid isobutylamide.

ever, the summation of extracted dry weight of 1st- and 2nd-step extractions was over $90 \%$ of total extract dry weight obtained through three-step extractions.

The contents of total phenols also differed significantly among the sequentially prepared 1st, 2nd and 3rd extracts, with the highest amount of total phenols were obtained from the 1st extract (Table 1). When the total extraction yields were taken into consideration, total phenols content of the two-steps and three-steps sequential extractions were $834.72 \mathrm{mg}$ and $911.63 \mathrm{mg}$, respectively. The calculated total phenols content of freeze-dried $E$. purpurea flowers was $60.78 \mathrm{mg} / \mathrm{g}$ (Table 1 ).

As for the contents of caffeic acid derivatives in the aqueous ethanol extracts (Table 1), the cichoric acid (72.60\% - 73.15\%) represented the highest portion of phenolic substance, followed by caftaric acid (21.94\% $22.94 \%)$, chlorogenic acid (2.85\% - 3.27\%), echinacoside (1.20\% - 1.28\%), and caffeic acid $(0.44 \%-0.45 \%)$. These results are in agreement with the report of Tsai et al. [13]. No significant differences in the contents of caffeic acid derivatives (except chlorogenic acid) existed among the 1st, 2nd and 3rd extract. When the total extraction yields were taken into consideration, the cichoric acid, caftaric acid, chlorogenic acid, echinacoside and caffeic acid content obtained from $15 \mathrm{~g}$ sample were 335.06, 100.85, 14.23, 5.52 and $2.03 \mathrm{mg}$, respectively. The summation of cichoric acid, caftaric acid, chlorogenic acid, echinacoside and caffeic acid from 1st and 2nd extracts was $91.95 \%, 91.54 \%, 92.99 \%, 91.40 \%$, and $91.89 \%$, with the estimated contents (on freeze-dried flowers base) of 22.34, 6.72, 0.95, 0.37, and $0.14 \mathrm{mg} / \mathrm{g}$, respectively (Table 1 ).

Many alkamides have been isolated and identified from the root, leaves and flowers of $E$. purpurea, with alkamide 8/9 being predominant [21]. Therefore, only alkamide 8/9 were measured in this study. As shown in Table 1, alkamide 8/9 were detectable in 1st, 2nd and 3rd extracts, and the contents of these compounds were progressively increased from 505.38 to $598.61 \mu \mathrm{g} / \mathrm{g}$ extract. When the total extraction yields were taken into consideration, the contents of alkamide $8 / 9$ of the two-steps and three-steps sequential extractions were 2469.74 and $2724.24 \mu \mathrm{g}$, respectively. Nevertheless, the summation of alkamide $8 / 9$ from 1 st and 2nd extracts was $90.66 \%$. The calculated alkamide 8/9 content of freeze-dried E. purpurea flowers was $181.62 \mu \mathrm{g} / \mathrm{g}$ (Table 1).

\subsection{Effect of Multi-Steps Sequential Extraction Method on the Antioxidant Properties}

In this study, DPPH radical scavenging abilities of 1st, 2nd, and 3rd flower extracts plus three reference antioxidative compounds (ascorbic acid, BHA and $\alpha$-tocopherol) presented in Figure 1(a) demonstrated dose-de- 


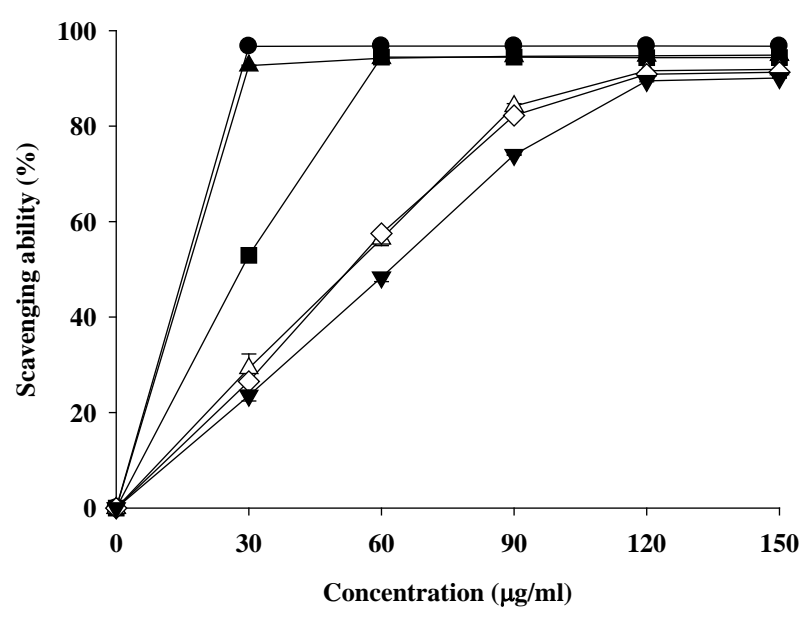

(a)

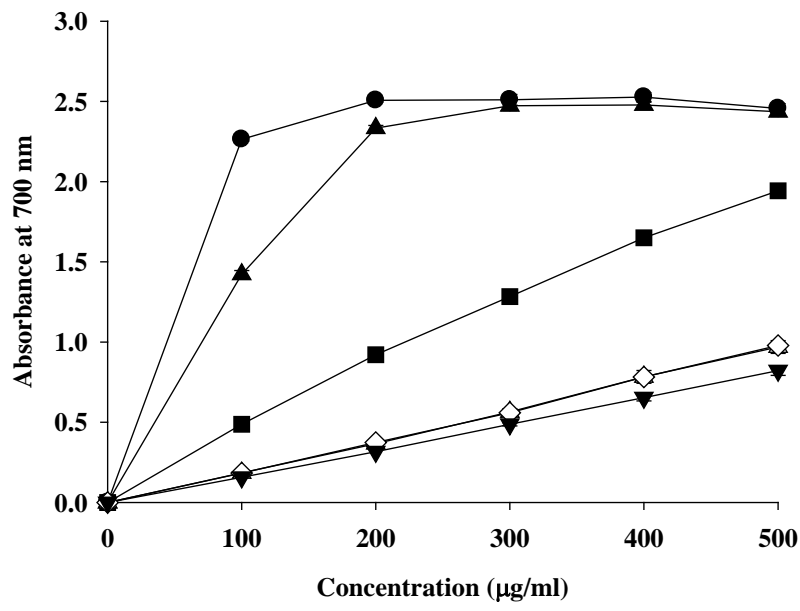

(b)

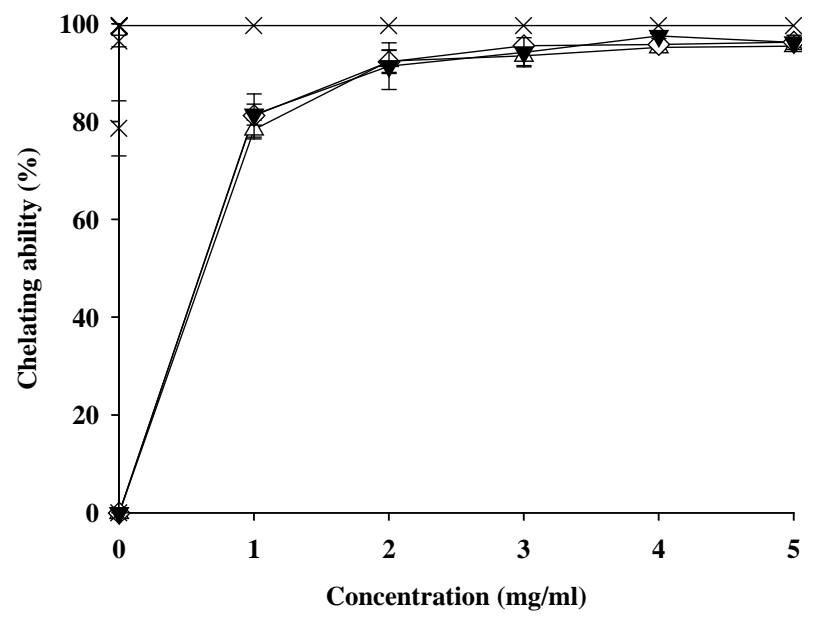

(c)

Figure 1. Antioxidant properties of standards and extracts from freeze-dried Echinacea purpurea flower with different three time extraction. Each value is expressed as mean \pm standard deviation (n $=3$ ). Ascorbic acid $(\bullet)$, Butylated hydroxyanisole $(\boldsymbol{\Delta})$, and $\alpha$-Tocopherol ( $\mathbf{a})$ for scavenging ability on DPPH radicals and reducing power. Ethylenediaminetetraacetic acid $(\times)$ for chelating ability on ferrous ions. 1st extract $(\Delta)$, 2nd extract $(\diamond)$, 3rd extract $(\boldsymbol{\nabla})$. (a) Scavenging ability on DPPH radicals; (b) Reducing power; (c) Chelating ability on ferrous ions. 
pendent responses. The DPPH radical scavenging abilities of 1st, 2nd, and 3rd extracts were lower than those of references. At $30 \mu \mathrm{g} / \mathrm{ml}$ dose, the scavenging abilities of tested samples on DPPH radicals were in the descending order of ascorbic acid $(96.71 \%)>$ BHA $(92.67 \%)>\alpha$-tocopherol $(52.94 \%)>1$ st extract $(29.28 \%) \approx 2 \mathrm{nd} \mathrm{ex-}$ tract $(26.52 \%)>$ 3rd extract $(23.55 \%)$. The estimated $\mathrm{EC}_{50}$ values of ascorbic acid, BHA, $\alpha$-tocopherol, 1 st extract, 2nd extract, and 3rd extract for DPPH radical scavenging ability were $15.51 \mu \mathrm{g} / \mathrm{ml}, 16.19 \mu \mathrm{g} / \mathrm{ml}, 28.34$ $\mu \mathrm{g} / \mathrm{ml}, 52.87 \mu \mathrm{g}$ extract/ml (9.63 $\mu \mathrm{g}$ total phenols/ml), $52.39 \mu \mathrm{g}$ extract/ml (9.24 $\mu \mathrm{g}$ total phenols/ml), and 61.45 $\mu \mathrm{g}$ extract/ml (10.88 $\mu \mathrm{g}$ total phenols/ml), respectively. The DPPH scavenging abilities of E. purpurea flower extract may be attributable to its high contents of caffeic acid derivatives, particularly the dominant presence of the cichoric acid (Table 1). The radical scavenging activity by the DPPH method depends on the number and substitution pattern of hydroxyl groups. Pellati et al. [3] reported that the cichoric acid had two adjacent hydroxyl groups on its phenolic rings, therefore it tended to have higher DPPH radical scavenging ability than other caffeic acid derivatives. The high DPPH scavenging ability of cichoric acid in E. purpurea leaf extract was also reported by Thygesen et al. [9].

The reducing powers of 1st, 2nd, and 3rd flower extracts in Figure 1(b) also exhibited dose-dependent responses. At $100 \mu \mathrm{g} / \mathrm{ml}$ dose, the reducing powers of samples were in the descending order of ascorbic acid (2.264 AU) $>$ BHA (1.422 AU) > $\alpha$-tocopherol (0.487 AU) $>1$ st extract $(0.184 \mathrm{AU}) \approx 2$ 2nd extract $(0.183 \mathrm{AU})>3 \mathrm{rd}$ extract $(0.157 \mathrm{AU})$. The estimated $\mathrm{EC}_{50}$ values of 1st extract, 2nd extract, and 3rd extract for reducing power were $264.98 \mu \mathrm{g}$ extract $/ \mathrm{ml}$ (48.25 $\mu \mathrm{g}$ total phenols/ml), $268.74 \mu \mathrm{g}$ extract $/ \mathrm{ml}$ (47.39 $\mu \mathrm{g}$ total phenols $/ \mathrm{ml})$, and $309.05 \mu \mathrm{g}$ extract $/ \mathrm{ml}(54.73 \mu \mathrm{g}$ total phenols/ml), respectively. These values were significantly greater than the EC $_{50}$ values of $22.12 \mu \mathrm{g} / \mathrm{ml}, 35.13 \mu \mathrm{g} / \mathrm{ml}, 107.67 \mu \mathrm{g} / \mathrm{ml}$ obtained from ascorbic acid, BHA, $\alpha$-tocopherol, respectively.

Ferrous ions are the most effective pro-oxidants in the food system; therefore it is frequently used as an antioxidant assessment index [22] [23]. The ferrous ions chelating ability of flower extracts and reference compounds were illustrated in Figure 1(c). The ferrous ions chelating ability of ascorbic acid, BHA and $\alpha$-tocopherol were not detectable. The flower extracts exerted $>80 \%$ chelating effect at $1 \mathrm{mg} / \mathrm{ml}$ dosew when compared with the $10 \mu \mathrm{g} / \mathrm{ml}$ of EDTA. The $\mathrm{EC}_{50}$ values of 1st extract, 2nd extract, and 3rd extract for ferrous ions chelating ability were $637.99 \mu \mathrm{g}$ extract/ml (116.17 $\mu \mathrm{g}$ total phenols $/ \mathrm{ml}), 616.74 \mu \mathrm{g}$ extract/ml $(108.75 \mu \mathrm{g}$ total phenols/ml), and $614.04 \mu \mathrm{g}$ extract/ml (108.73 $\mu \mathrm{g}$ total phenols/ml), respectively. The ferrous ions chelating ability of E. purpurea flower extracts may be attributed to the adjacent hydroxyl and carbonyl groups in its flavanol structure, which could chelate ferrous ion to form a complex [24].

\subsection{Effect of Multi-Batches Extraction Method on the Extraction Yields and Active Compounds}

The extraction dry weight of extract was increased significantly with increasing the number of extraction batches (Table 2), but with a concomitant decline in extraction yield. The contents of total phenols in I, II, III, and IV batch extracts varied between 177.25 and $186.92 \mathrm{mg}$ CAE/g extract (Table 2). When the total extraction yields were taken into consideration, total phenols content of I, II, III, and IV extracts obtained from 15, 30, 45, and 60 g sample were 558.70, 924.94, 1278.63, and $1404.63 \mathrm{mg}$, respectively. The obtained total phenols content (mg CAE/g freeze-dried flowers) in the tested I, II, III, and IV batches was 37.25, 30.83, 28.41, and 23.41, respectively (Table 3 ).

As shown in Table 2, the contents of chlorogenic acid, caffeic acid, echinacoside, cichoric acid, and total caffeic acid derivatives (except caftaric acid) were not significantly different among the tested extracts. The cichoric acid (73.89\% - 74.47\%) was the major phenolic substance, followed by caftaric acid (20.50\% - 21.24\%), chlorogenic acid (3.07\% - 3.22\%), echinacoside (1.29\% - 1.36\%), and caffeic acid $(0.45 \%-0.50 \%)$. When the total extraction yields were taken into consideration, the calculated individual and total caffeic acid derivatives contents (mg/g freeze-dried flowers) of freeze-dried E. purpurea flowers was I > II > III > IV (Table 3).

The contents of alkamide 8/9 in I, II, III, and IV batch extracts was decreased with increasing the number of batch, ranging from 534.36 to $269.76 \mu \mathrm{g} / \mathrm{g}$ extract (Table 2). When the total extraction yields were taken into consideration in this study, the contents of alkamide 8/9 in I, II, III, and IV extract samples were 1597.95, 2396.03, 3115.30, and 2101.21 $\mu$ g, respectively. The estimated alkamide 8/9 content ( $\mu \mathrm{g} / \mathrm{g}$ freeze-dried flowers) of freeze-dried E. purpurea flowers was I > II > III > IV (Table 3). 
Table 2. The weight, extraction yields and active compounds contents of freeze-dried extracts from freeze-dried Echinacea purpurea flower with multi-batches extraction method.

\begin{tabular}{|c|c|c|c|c|}
\hline \multirow{2}{*}{ Quality characteristics } & \multicolumn{4}{|c|}{ Multi-batches extraction } \\
\hline & $\mathbf{I}$ & II & III & IV \\
\hline Weight (g) & $2.9904 \pm 0.0807 \mathrm{D}^{a}$ & $5.2183 \pm 0.0971 \mathrm{C}$ & $6.8405 \pm 0.0297 \mathrm{~B}$ & $7.7892 \pm 0.1327 \mathrm{~A}$ \\
\hline Extraction yield $^{b}(\%)$ & $19.93 \pm 0.53 \mathrm{~A}$ & $17.39 \pm 0.33 \mathrm{~B}$ & $15.20 \pm 0.07 \mathrm{C}$ & $12.98 \pm 0.22 \mathrm{D}$ \\
\hline Total phenols (mg CAE/g) & $186.83 \pm 5.03 \mathrm{~A}$ & $177.25 \pm 2.05 \mathrm{~A}$ & $186.92 \pm 8.91 \mathrm{~A}$ & $180.33 \pm 2.53 \mathrm{~A}$ \\
\hline \multicolumn{5}{|l|}{ Caffeic acid derivatives (mg/g) } \\
\hline Caftaric acid & $20.08 \pm 0.20 \mathrm{~A}$ & $19.19 \pm 0.70 \mathrm{AB}$ & $18.47 \pm 0.32 \mathrm{AB}$ & $18.03 \pm 1.43 \mathrm{~B}$ \\
\hline Chlorogenic acid & $2.92 \pm 0.17 \mathrm{~A}$ & $2.82 \pm 0.19 \mathrm{~A}$ & $2.90 \pm 0.08 \mathrm{~A}$ & $2.71 \pm 0.36 \mathrm{~A}$ \\
\hline Caffeic acid & $0.48 \pm 0.09 \mathrm{~A}$ & $0.41 \pm 0.01 \mathrm{~A}$ & $0.44 \pm 0.04 \mathrm{~A}$ & $0.42 \pm 0.04 \mathrm{~A}$ \\
\hline Echinacoside & $1.27 \pm 0.25 \mathrm{~A}$ & $1.17 \pm 0.06 \mathrm{~A}$ & $1.19 \pm 0.17 \mathrm{~A}$ & $1.17 \pm 0.12 \mathrm{~A}$ \\
\hline Cichoric acid & $70.31 \pm 3.54 \mathrm{~A}$ & $66.76 \pm 3.03 \mathrm{~A}$ & $67.09 \pm 0.92 \mathrm{~A}$ & $63.66 \pm 5.32 \mathrm{~A}$ \\
\hline Total caffeic acid derivatives & $95.06 \pm 4.09 \mathrm{~A}$ & $90.35 \pm 3.73 \mathrm{~A}$ & $90.09 \pm 1.02 \mathrm{~A}$ & $85.99 \pm 7.18 \mathrm{~A}$ \\
\hline Alkamide $8 / 9^{c}(\mu \mathrm{g} / \mathrm{g})$ & $534.36 \pm 40.94 \mathrm{~A}$ & $459.16 \pm 8.57 \mathrm{~B}$ & $455.42 \pm 33.26$ B & $269.76 \pm 8.81 \mathrm{C}$ \\
\hline
\end{tabular}

${ }^{a}$ Each value is expressed as mean \pm standard deviation $(\mathrm{n}=3)$. Means with different capital letter within a row are significantly different $(P<0.05)$; ${ }^{b}$ Extraction yield $(\%)=($ dried extract weight/sample weight $) \times 100 \%{ }^{c}{ }^{c}$ Alkamide $8 / 9$ : dodeca-2E, $4 E, 8 Z, 10(E / Z)$-tetraenoic acid isobutylamide.

Table 3. Active compounds contents of freeze-dried Echinacea purpurea flower with multi-batches extraction method.

\begin{tabular}{ccccc}
\hline Quality characteristics & \multicolumn{4}{c}{ Multi-batch extraction } \\
\cline { 2 - 5 } & I & II & III & IV \\
\hline $\begin{array}{c}\text { Total phenols (mg CAE/g flower) } \\
\text { Caffeic acid derivatives (mg/g flower) }\end{array}$ & $37.25 \pm 0.25 \mathrm{~A}^{a}$ & $30.83 \pm 0.57 \mathrm{~B}$ & $28.41 \pm 1.16 \mathrm{C}$ & $23.41 \pm 0.59 \mathrm{D}$ \\
Caftaric acid & & & & \\
Chlorogenic acid & $4.00 \pm 0.07 \mathrm{~A}$ & $3.34 \pm 0.09 \mathrm{~B}$ & $2.81 \pm 0.05 \mathrm{C}$ & $2.34 \pm 0.20 \mathrm{D}$ \\
Caffeic acid & $0.58 \pm 0.04 \mathrm{~A}$ & $0.49 \pm 0.03 \mathrm{~B}$ & $0.44 \pm 0.01 \mathrm{~B}$ & $0.35 \pm 0.05 \mathrm{C}$ \\
Echinacoside & $0.10 \pm 0.02 \mathrm{~A}$ & $0.07 \pm<0.01 \mathrm{~B}$ & $0.07 \pm 0.01 \mathrm{~B}$ & $0.05 \pm 0.01 \mathrm{~B}$ \\
Cichoric acid & $0.25 \pm 0.04 \mathrm{~A}$ & $0.20 \pm 0.01 \mathrm{~B}$ & $0.18 \pm 0.03 \mathrm{~B}$ & $0.15 \pm 0.02 \mathrm{~B}$ \\
Total caffeic acid derivatives & $14.02 \pm 0.33 \mathrm{~A}$ & $11.61 \pm 0.31 \mathrm{~B}$ & $10.20 \pm 0.16 \mathrm{C}$ & $8.26 \pm 0.69 \mathrm{D}$ \\
Alkamide 8/9 $\mathbf{9}^{b} \boldsymbol{\mu g} / \mathbf{g}$ flower) & $18.95 \pm 0.32 \mathrm{~A}$ & $15.72 \pm 0.38 \mathrm{~B}$ & $13.69 \pm 0.20 \mathrm{C}$ & $11.16 \pm 0.95 \mathrm{D}$ \\
\hline
\end{tabular}

${ }^{a}$ Each value is expressed as mean \pm standard deviation $(n=3)$. Means with different capital letter within a row are significantly different $(P<0.05)$; ${ }^{b}$ Alkamide 8/9: dodeca-2E, 4E, 8Z, 10(E/Z)-tetraenoic acid isobutylamide.

\subsection{Effect of Multi-Batches Extraction Method on the Antioxidant Properties}

DPPH radical scavenging abilities of I, II, III, and IV flower extracts plus three reference chemicals (ascorbic acid, BHA and $\alpha$-tocopherol) presented in Figure 2(a) also demonstrated dose-dependent responses. The DPPH radical scavenging abilities of I, II, III, and IV flower extracts were lower than those of reference chemicals. At $30 \mu \mathrm{g} / \mathrm{ml}$ dose, the scavenging abilities of tested samples on DPPH radicals are in the descending order of ascorbic acid $(96.71 \%)>$ BHA $(92.67 \%)>\alpha$-tocopherol $(52.94 \%)>$ I extract $(28.36 \%) \approx$ II extract $(26.49 \%) \approx$ III extract $(28.77 \%) \approx$ IV extract $(26.56 \%)$. The calculated $E_{50}$ values of I, II, III, and IV extracts in DPPH radical scavenging ability were $53.64 \mu \mathrm{g}$ extract/ml $(10.02 \mu \mathrm{g}$ total phenols $/ \mathrm{ml}), 53.43 \mu \mathrm{g}$ extract/ml $(9.47 \mu \mathrm{g}$ total phe- 


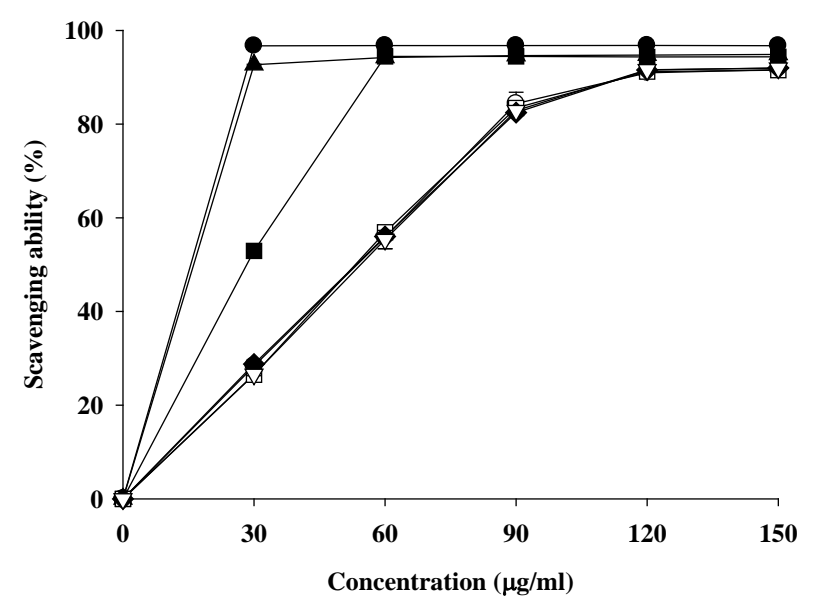

(a)

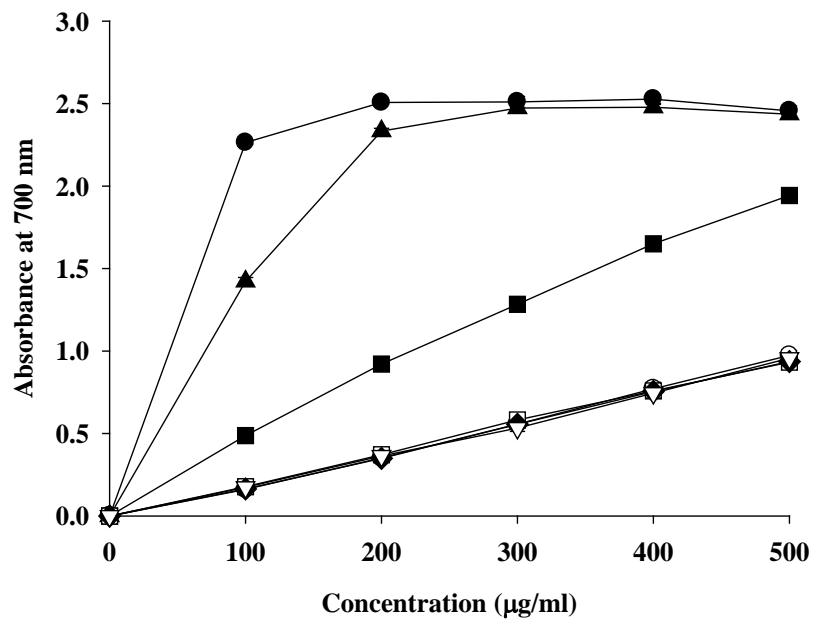

(b)

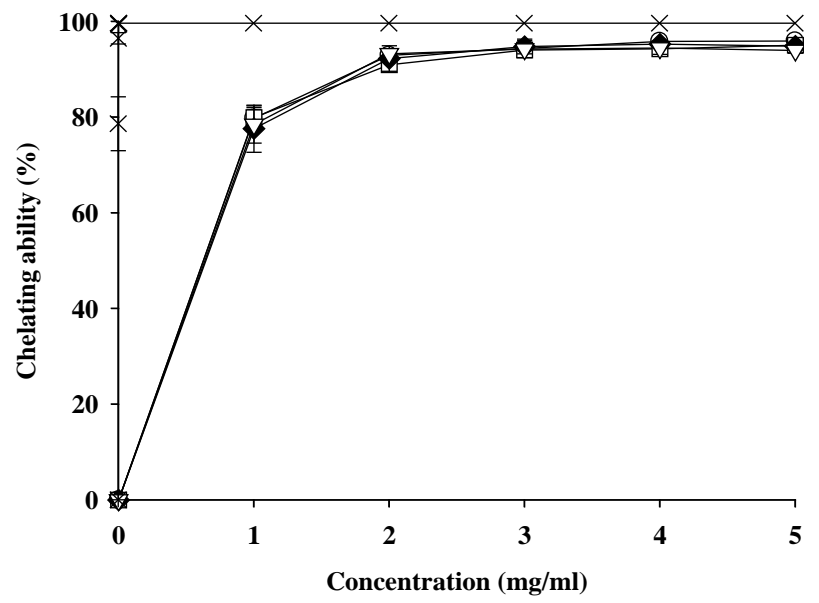

(c)

Figure 2. Antioxidant properties of standards and extracts from freeze-dried Echinacea purpurea flower with different batches extraction. Each value is expressed as mean \pm standard deviation ( $\mathrm{n}=$ 3). Ascorbic acid $(\bullet)$, Butylated hydroxyanisole $(\boldsymbol{\Delta})$, and $\alpha$-Tocopherol $(\boldsymbol{\bullet})$ for scavenging ability on DPPH radicals and reducing power. Ethylenediaminetetraacetic acid $(\times)$ for chelating ability on ferrous ions. I (०), II ( $\square)$, III ( $)$, IV ( $\nabla)$. (a) Scavenging ability on DPPH radicals; (b) Reducing power; (c) Chelating ability on ferrous ions. 
nols $/ \mathrm{ml}), 53.30 \mu \mathrm{g}$ extract $/ \mathrm{ml}$ (9.96 $\mu \mathrm{g}$ total phenols $/ \mathrm{ml})$, and $54.66 \mu \mathrm{g}$ extract $/ \mathrm{ml}$ (9.86 $\mu \mathrm{g}$ total phenols/ml), respectively.

The reducing powers of I, II, III, and IV extracts in Figure 2(b) also exhibited dose-dependent responses. The calculated $\mathrm{EC}_{50}$ values ( $\mu \mathrm{g}$ extract $/ \mathrm{ml}$ ) for I, II, III, and IV extracts in reducing power were $274.34 \mu \mathrm{g}$ extract $/ \mathrm{ml}$ (51.25 $\mu \mathrm{g}$ total phenols $/ \mathrm{ml}), 267.99 \mu \mathrm{g}$ extract $/ \mathrm{ml}$ (47.50 $\mu \mathrm{g}$ total phenols $/ \mathrm{ml}), 273.82 \mu \mathrm{g}$ extract $/ \mathrm{ml}$ (51.18 $\mu \mathrm{g}$ total phenols/ml), and $283.68 \mu \mathrm{g}$ extract $/ \mathrm{ml}(51.16 \mu \mathrm{g}$ total phenols $/ \mathrm{ml})$, respectively.

The ferrous ions chelating ability of I, II, III, and IV extracts and reference compounds were illustrated in Figure 2(c). The flower extracts demonstrated $70 \%-80 \%$ chelating effect at $1 \mathrm{mg} / \mathrm{ml}$ dose comparing to 10 $\mu \mathrm{g} / \mathrm{ml}$ of EDTA (Figure 2(c)). The estimated EC $_{50}$ values of I, II, III, and IV extracts in ferrous ions chelating ability were $626.89 \mu \mathrm{g}$ extract $/ \mathrm{ml}(117.12 \mu \mathrm{g}$ total phenols $/ \mathrm{ml}), 625.69 \mu \mathrm{g}$ extract $/ \mathrm{ml}(110.90 \mu \mathrm{g}$ total phenols $/ \mathrm{ml}), 646.03 \mu \mathrm{g}$ extract $/ \mathrm{ml}(120.76 \mu \mathrm{g}$ total phenols $/ \mathrm{ml})$, and $638.27 \mu \mathrm{g}$ extract $/ \mathrm{ml}(115.10 \mu \mathrm{g}$ total phenols/ml), respectively.

\subsection{Comparisons of Quality Characteristics of Freeze-Dried Flowers among Extraction Methods}

In multi-steps sequential extraction, the total extract weight of two- and three-steps extraction obtained from 15 g freeze-dried E. purpurea flowers were 4.6286 and 5.0629 g, respectively (Table 1). When the results are recalculated and expressed on $60 \mathrm{~g}$ freeze-dried flowers base, the estimated total extract weights for two- and three-steps sequential extraction is around 18.5144 and 20.2516 g, respectively (Table 4). In multi-batches extraction method, the extract weight obtained from IV batches of extraction was only $7.7892 \mathrm{~g}$ (Table 2).

The contents of total phenols of two- and three-steps sequential extraction obtained from $15 \mathrm{~g}$ freeze-dried flowers were 834.72 and $911.63 \mathrm{mg}$, respectively (Table 1). The total phenols content of two- and three-steps sequential extraction obtained from $60 \mathrm{~g}$ freeze-dried flowers were 3338.88 and $3646.52 \mathrm{mg}$, respectively (Table 4). In multi-batches extraction, total phenols of IV sample (60 g) only was $1404.26 \mathrm{mg}$, which is about $42.1 \%$ and $38.5 \%$ of two- and three-steps sequential extraction obtained from $60 \mathrm{~g}$ freezed-dried flowers, respectively. The total caffeic acid derivatives content of two- and three-steps sequential extraction obtained from $15 \mathrm{~g}$ freezed-dried flowers were 420.55 and $457.68 \mathrm{mg}$, respectively (Table 1). The total caffeic acid derivatives content of two- and three-steps sequential extraction obtained from $60 \mathrm{~g}$ freezed-dried flowers were 1686.20 and $1830.72 \mathrm{mg}$, respectively (Table 4). In multi-batches extraction, the total caffeic acid derivatives content of IV sample (60 g) only was $669.79 \mathrm{mg}$, which was about $39.8 \%$ and $36.6 \%$ of two and three sequential extractions obtained from $60 \mathrm{~g}$ freezed-dried flowers, respectively.

The alkamide 8/9 content of two- and three-steps sequential extraction obtained from $15 \mathrm{~g}$ freezed-dried flowers was 2469.74 and $2724.24 \mu \mathrm{g}$, respectively (Table 1). The alkamide content of two- and three-steps sequential extraction obtained from $60 \mathrm{~g}$ freezed-dried flowers was 9878.96 and $10896.96 \mu \mathrm{g}$, respectively (Table 4). In multi-batches extraction, the alkamide $8 / 9$ of IV sample (60 g) only was $2101.21 \mu \mathrm{g}$, which was about $21.3 \%$ and $19.3 \%$ of two- and three-steps sequential extraction obtained from $60 \mathrm{~g}$ freeze-dried flowers, respectively.

When the amounts of recovered ethanol were taken into consideration, the consumption of $50 \%$ aqueous ethanol in two- and three-steps sequential extraction method for $15 \mathrm{~g}$ freeze-dried flowers were 98.1 and 124.7 $\mathrm{ml}$, respectively. The total consumption of $50 \%$ aqueous ethanol of two- and three-steps sequential extraction for $60 \mathrm{~g}$ freezed-dried flowers was 392.4 and $498.8 \mathrm{ml}$, respectively (Table 4). On the other hand, the consumption of 50\% aqueous ethanol for IV batch extraction sample was $217.9 \mathrm{ml}$ (Table 4).

Table 4. Comparison of total extract weight, active compounds, and ethanol consumption of freeze-dried E. purpurea flower with multi-steps and multi-batches extraction methods. ${ }^{a}$

\begin{tabular}{|c|c|c|c|c|c|}
\hline Extraction method ${ }^{b}$ & $\begin{array}{c}\text { Total extract } \\
\text { weight (g) }\end{array}$ & $\begin{array}{l}\text { Total phenols } \\
\text { (mg CAE) }\end{array}$ & $\begin{array}{l}\text { Total caffeic acid } \\
\text { derivatives (mg) }\end{array}$ & $\begin{array}{c}\text { Alkamide } \\
8 / 9^{c}(\mu \mathrm{g})\end{array}$ & $\begin{array}{c}50 \% \text { Ethanol } \\
\text { consumption }(\mathrm{ml})\end{array}$ \\
\hline Two-steps sequential extraction & 18.5144 & 3338.88 & 1682.20 & 9878.96 & 392.4 \\
\hline Three-steps sequential extraction & 20.2516 & 3646.52 & 1830.72 & 10896.96 & 498.8 \\
\hline Multi-batches extraction IV & 7.7892 & 1404.62 & 669.79 & 2101.21 & 217.9 \\
\hline
\end{tabular}

${ }^{a}$ The quality characteristics result calculated on the basis of $60 \mathrm{~g}$ freezed-dried flowers. ${ }^{b}$ Multi-steps extraction 1 and 2 indicated that 2 and 3 sequential extraction, respectively, in multi-steps extraction method. Multi-batches extraction IV: same as Table 2. ${ }^{c}$ Alkamide $8 / 9$ : dodeca-2E, $4 E$, 8Z, 10(E/Z)-tetraenoic acid isobutylamide. 


\section{Conclusion}

The weight and yield of extract were decreased significantly different with increased number of extraction in multi-steps extraction. The increased extract weight was not proportioned to the sample batches in multi-batch extraction. The total phenols, individual and total caffeic acid derivatives content of extracts were not significantly different obtained from multi-steps or multi-batches extractions. The alkamide 8/9 contents of extracts were 2 nd $\approx 3$ rd $>1$ st in multi-steps extraction, and I > II $\approx$ III $>$ IV in multi-batches extraction. When the total extraction yields were taken into consideration, the results showed that 1 st $>2$ nd $>$ 3rd in multi-steps extraction, and I > II > III > IV in multi-batches extraction. Thus, the optimal extraction method is recommended to be two-steps sequential extraction, when the extract weight, active compounds content, and ethanol consumption were taken into consideration.

\section{Acknowledgements}

The authors would like to thank National Science Council of Taiwan for financially supporting this research under Grant No. NSC 100-2622-E-241-005-CC3.

\section{References}

[1] Barnes, J., Anderson, L.A., Gibbons, S. and Phillipson, J. D. (2005) Echinacea species (Echinacea angustifolia (DC.) Hell., Echinacea pallida (Nutt.) Nutt., Echinacea purpurea (L.) Moench): A Review of Their Chemistry, Pharmacology and Clinical Properties. Journal of Pharmacy and Pharmacology, 57, 929-954. http://dx.doi.org/10.1211/0022357056127

[2] Bauer, R. and Wagner, H. (1991) Echinacea Species as Potential Immunostimulating Drugs. In: Wagner, H. and Farnsworth, N.R., Eds., Economic and Medicinal Plant Research, Vol. 5, Academic Press, New York, 253-321.

[3] Pellati, F., Benvenuti, S., Magro, L., Melegari, M. and Soragni, F. (2004) Analysis of Phenolic Compounds and Radical Scavenging Activity of Echinacea spp. Journal of Pharmaceutical and Biomedical Analysis, 35, 289-301. http://dx.doi.org/10.1016/S0731-7085(03)00645-9

[4] Tsai, Y.L., Chiu, C.C., Chen, J.Y.F., Chan, K.C. and Lin, S.D. (2012) Cytotoxic Effects of Echinacea purpurea Flower Extracts and Cichoric Acid on Human Colon Cancer Cells through Induction of Apoptosis. Journal of Ethnopharmacology, 143, 914-919.

[5] Gertsch, J., Schoop, R., Kuenzle, U. and Suter, A. (2004) Echinacea Alkylamides Modulate TNF- $\alpha$ Gene Expression via Cannabinoid Receptor CB2 and Multiple Signal Transduction Pathways. FEBS Letters, 577, 563-569. http://dx.doi.org/10.1016/j.febslet.2004.10.064

[6] Raduner, S., Majewska, A., Chen, J.Z., Xie, X.Q., Hamon, J., Faller, B., Altmann, K.H. and Gertsch, J. (2006) Alkylamides from Echinacea Are a New Class of Cannabinomimetics. The Journal of Biological Chemistry, 281, 1419214206. http://dx.doi.org/10.1074/jbc.M601074200

[7] Wagner, H. (1989) Search for New Plant Constituents with Potential Antiphlogistic and Antiallergic Activity. Planta Medica, 55, 235-241. http://dx.doi.org/10.1055/s-2006-961992

[8] Woelkart, K., Marth, E., Suter, A., Schoop, R., Raggam, R.B., Koidl, C., Kleinhappl, B. and Bauer, R. (2006) Bioavailability and Pharmacokinetics of Echinacea purpurea Preparations and Their Interaction with the Immune System. International Journal of clinical Pharmacology and Therapeutics, 44, 401-408. http://dx.doi.org/10.5414/CPP44401

[9] Thygesen, L., Thulinn, J., Mortensen, A., Skibsted, L.H. and Molgaard, P. (2007) Antioxidant Activity of Cichoric Acid and Alkamides from Echinacea purpurea, Alone and in Combination. Food Chemistry, 101, 74-81. http://dx.doi.org/10.1016/j.foodchem.2005.11.048

[10] Wang, L. and Weller, C.L. (2006) Recent Advances in Extraction of Nutraceuticals from Plants. Trends in Food Science and Technology, 17, 300-312. http://dx.doi.org/10.1016/j.tifs.2005.12.004

[11] Wu, C.H., Murthy, H.N., Hahn, E.J., Lee, H.L. and Paek, K.Y. (2008) Efficient Extraction of Caffeic Acid Derivatives from Adventitious Roots of Echinacea purpurea. Czech Journal of Food Sciences, 26, 254-258.

[12] Lin, S.D., Sung, J.M. and Chen, C.L. (2011) Effect of Drying and Storage Conditions on Caffeic Acid Derivatives and total Phenolics of Echinacea purpurea Grown in Taiwan. Food Chemistry, 125, 226-231. http://dx.doi.org/10.1016/j.foodchem.2010.09.006

[13] Tsai, Y.L., Chiou, S.Y., Chan, K.C., Sung, J.M. and Lin, S.D. (2012) Caffeic Acid Derivatives, Total Phenols, Antioxidant and Antimutagenic Activities of Echinacea purpurea Flower Extracts. LWT-Food Science and Technology, 46, 169-176. http://dx.doi.org/10.1016/j.lwt.2011.09.026

[14] Goli, A.H., Barzegar, M. and Sahari, M.A. (2004) Antioxidant Activity and Total Phenolic Compounds of Pistachio 
(Pistachia vera) Hull Extracts. Food Chemistry, 92, 521-525. http://dx.doi.org/10.1016/j.foodchem.2004.08.020

[15] Hu, C. and Kitts, D.D. (2000) Studies on the Antioxidant of Echinacea Root Extract. Journal of Agricultural and Food Chemistry, 48, 1466-1472. http://dx.doi.org/10.1021/jf990677+

[16] Perry, N.B., Klink, J.W.V., Burgess, E.J. and Parmenter, G.A. (1997) Alkamide Levels in Echinacea purpurea: A Rapid Analytical Method Revealing Differences among Roots, Rhizomes, Stems, Leaves and Flowers. Planta Medica, 63, 58-62. http://dx.doi.org/10.1055/s-2006-957605

[17] Bergeron, C., Livesey, J.F., Awang, D.V.C., Arnason, J.T., Rana, J., Baum, B.R. and Letchamo, W. (2000) A Quantitative HPLC Method for the Quality Assurance of Echinacea Products on the North American Market. Phytochemical Analysis, 11, 207-215. http://dx.doi.org/10.1002/1099-1565(200007/08)11:4<207::AID-PCA519>3.0.CO;2-T

[18] Shimada, K., Fujikawa, K., Yahara, K. and Nakamura, T. (1992) Antioxidative Properties of Xanthan on the Autoxidation of Soybean Oil in Cyclodextrin Emulsion. Journal of Agricultural and Food Chemistry, 40, 945-948. http://dx.doi.org/10.1021/jf00018a005

[19] Oyaizu, M. (1986) Studies on Products of Browning Reactions: Antioxidative Activities of Products of Browning Reaction Prepared from Glucosamine. Japanese Journal of Nutrition and Dietetics, 44, 307-315. http://dx.doi.org/10.5264/eiyogakuzashi.44.307

[20] Dinis, T.C.P., Madeira, V.M.C. and Almeida, L.M. (1994) Action of Phenolic Derivatives (Acetaminophen, Salicylate, and 5-Aminosalicylate) as Inhibitors of Membrane Lipid Peroxidation and as Peroxyl Radical Scavengers. Archives of Biochemistry and Biophysics, 315, 161-169. http://dx.doi.org/10.1006/abbi.1994.1485

[21] Hou, C.C., Chen, C.H., Yang, N.S., Chen, Y.P., Lo, C.P., Wang, S.Y., Tien, Y.J., Tsai, P.W. and Shyur, L.F. (2010) Comparative Metabolomics Approach Coupled with Cell- and Gene-Based Assays for Species Classification and AntiInflammatory Bioactivity Validation of Echinacea Plants. Journal of Nutritional Biochemistry, 21, 1045-1059. http://dx.doi.org/10.1016/j.jnutbio.2009.08.010

[22] Ebrahimzadeh, M.A., Pourmorad, F. and Bekhradnia, A.R. (2008) Iron Chelating Activity, Phenol and Flavonoid Content of Some Medicinal Plants from Iran. African Journal of Biotechnology, 7, 3188-3192.

[23] Yamauchi, R., Tatsumi, Y., Asano, M., Kato, K. and Ueno, Y. (1988) Effect of Metal Salts Fructose on the Autoxidation of Methyl Linoleate in Emulsions. Agricultural and Biological Chemistry, 52, 849-850. http://dx.doi.org/10.1271/bbb1961.52.849

[24] Shahidi, F., Janitha, P.K. and Wanasundara, P.D. (1992) Phenolic Antioxidants. Critical Reviews in Food Science and Nutrition, 32, 67-103. http://dx.doi.org/10.1080/10408399209527581 
Scientific Research Publishing (SCIRP) is one of the largest Open Access journal publishers. It is currently publishing more than 200 open access, online, peer-reviewed journals covering a wide range of academic disciplines. SCIRP serves the worldwide academic communities and contributes to the progress and application of science with its publication.

Other selected journals from SCIRP are listed as below. Submit your manuscript to us via either submit@scirp.org or Online Submission Portal.
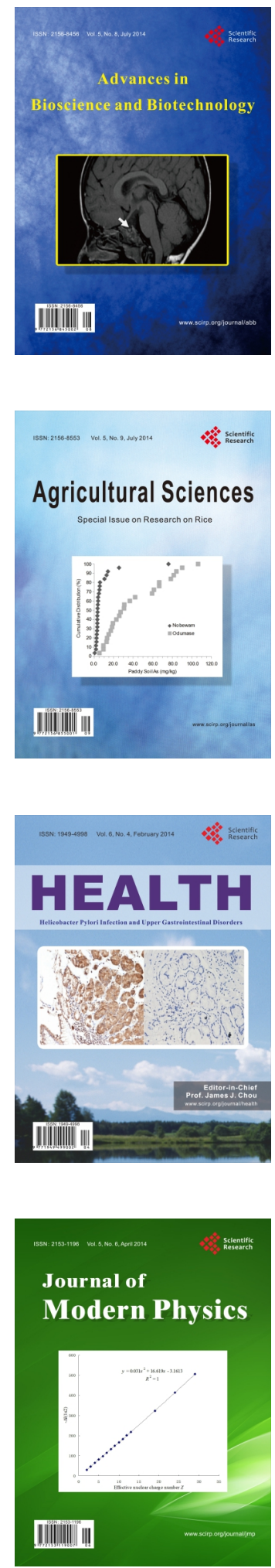
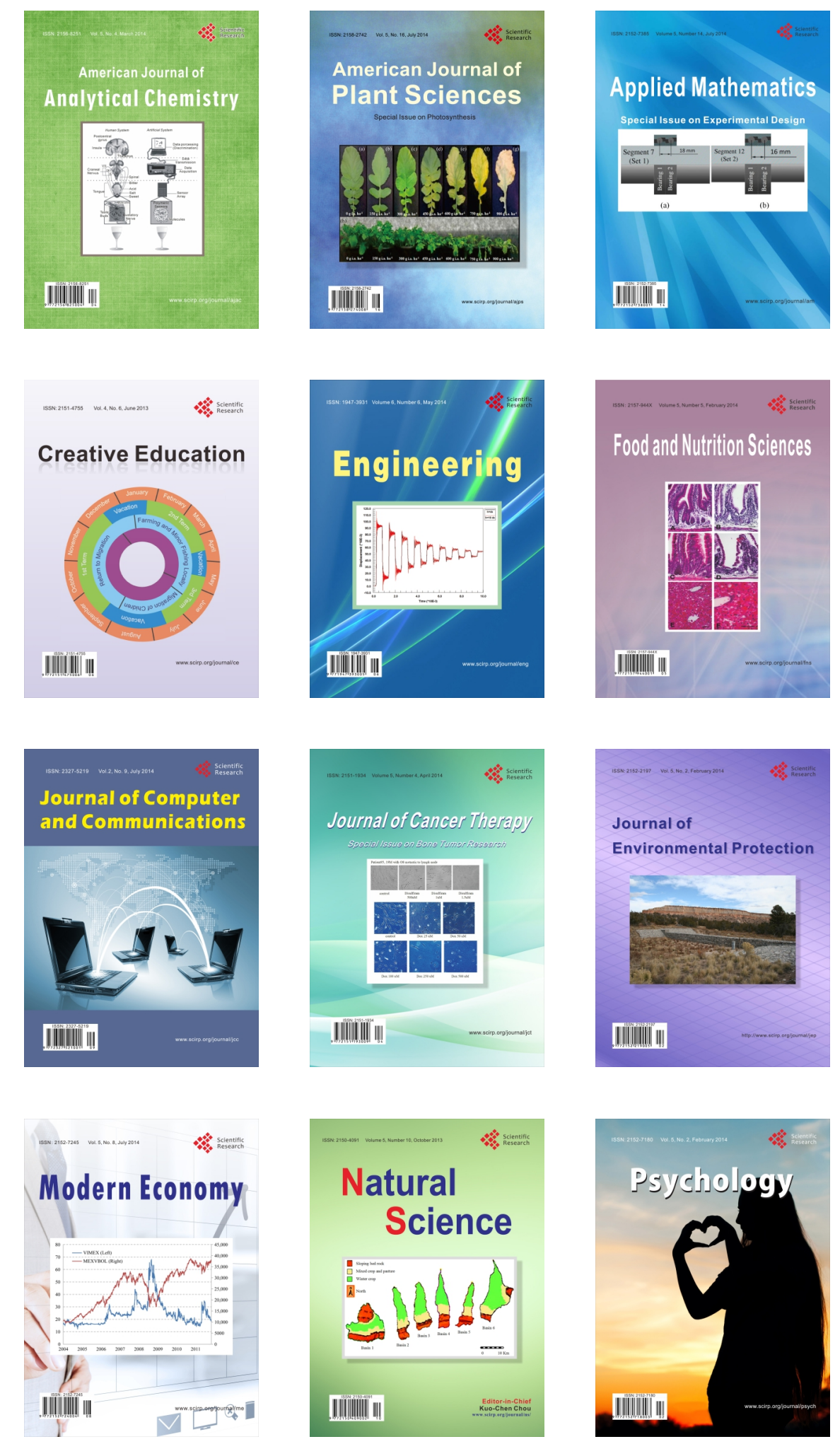